\title{
THE IMPACTS OF THE INTANGIBLE CULTURAL HERITAGE UNESCO POLICIES IN FRANCE
}

\section{LAURENT SÉBASTIEN FOURNIER}

The article focuses on the "Processional Giants and Dragons in Belgium and France" which were first introduced as a "Masterpiece of the Oral and Intangible Heritage of Humanity" in 2005. This case study documents the implementation of the UNESCO policies in France, analysing the differences between the initial project and its transformations a few years after the nomination. Different French candidatures are examined to understand the impacts of intangible cultural policies in France.

Keywords: UNESCO, intangible cultural heritage, economy, tourism, France.
Članek se osredinja na "Procesijske velikane in zmaje v Beligiji in Franciji», ki so bili leta 2005 predstavljeni kot "Mojstrovina ustne in nesnovne dedišcine človeštva". Študija primera dokumentira uveljavljanje Unescove politike $v$ Franciji $z$ analizo razločkov med začetnim načrtom in njegovim spreminjanjem $v$ nekaj letih po nominaciji. Obravnavani so različni francoski predlogi, ki osvetljujejo vplive politike nesnovne kulture v Franciji.

Ključne besede: UNESCO, nesnovna kulturna diedišcina, ekonomija, turizem, Francija.

\section{INTRODUCTION}

In this paper I would like to build on a report I've achieved in 2009 for the French Ministry of Culture concerning the impacts of the intangible cultural heritage nominations on tourism (Fournier 2009). The case study I'll specially focus on will be the "Processional Giants and Dragons in Belgium and France" which were first introduced as a "Masterpiece of the Oral and Intangible Heritage of Humanity" in 2005 and incorporated in 2008 in the "Representative List of the Intangible Cultural Heritage of Humanity".

I'll use this case study first to document the implementation of the UNESCO policies in France and to identify the actors who were involved before and after 2005 in the building up of the "Processional Giants and Dragons" application. Then I'll insist on the results of my fieldwork, showing how it helps to compare the views of the different actors, the impacts in the different towns concerned by the label, and the differences between the initial project and its transformations a few years after the nomination.

Lastly, I will examine the different French candidatures over the period 2005-2011 and compare the implementation of intangible cultural policies in France through these different examples. The analysis of available empirical data will eventually enlighten the impacts of intangible cultural heritage in France. 


\section{THE “PROCESSIONAL GIANTS AND DRAGONS” EXAMPLE}

To look closer at the "Processional Giants and Dragons" example, it is useful to consult first the UNESCO website. According to the UNESCO official presentation, under the label "Processional Giants and Dragons in Belgium and France" can be found traditional processions of huge effigies of giants, animals or dragons encompassing an original ensemble of festive popular manifestations and ritual representations. These effigies first appeared in urban religious processions at the end of the fourteenth century in many European towns and continue to serve as emblems of identity for certain Belgian (Ath, Brussels, Dendermonde, Mechelen and Mons) and French towns (Cassel, Douai, Pézenas and Tarascon), where they remain living traditions. The giants and dragons are large-scale models measuring up to nine metres in height and weighing as much as 350 kilos. They represent mythical heroes or animals, contemporary local figures, historical, biblical or legendary characters or trades.

The performances, often mixing secular procession and religious ceremony, vary from town to town, but always follow a precise ritual in which the giants relate to the history, legend or life of the town. Although these expressions are not threatened with immediate disappearance, the UNESCO suggests that they do suffer from a number of pressures, such as major changes to town centres and increasing tourism, leading to the detriment of the popular, spontaneous nature of the festival.

The "Processional Giants and Dragons in Belgium and France" were first introduced as a "Masterpiece of the Oral and Intangible Heritage of Humanity" in 2005. The proposal was supported both by France and Belgium. The 90 masterpieces proclaimed before the 2003 Convention for the Safaguarding of the Intangible Cultural Heritage entered into force were incorporated in 2008 in the "Representative List of the Intangible Cultural Heritage of Humanity". The Convention was adopted in 2006 by the French state. Since then, several new elements have been acknowledged as intangible cultural heritage and appear either on the representative or on the safeguarding list, as we will se further. However, the "Processional Giants and Dragons" remain the oldest elements. They have now been on the list for six years, which means that the people organizing or simply attending the processions may have had some time to learn about the Convention and its general scopes.

In 2009, I have been asked by the French Ministry of Culture to work on the impacts of the "Masterpiece of the Oral and Intangible Heritage of Humanity" UNESCO label in France. In practice, this meant I had to concentrate on the "Processional Giants and Dragons" only. Furthermore, it was decided to focus on the French towns only: Cassel and Douai near the Belgian border in the North, Pézenas and Tarascon on the Mediterranean coast in the South, were to be investigated in priority. I used the theoretical frame of my earlier works on the heritageization of local festivals to begin this fieldwork. Ten years ago, I had tried to suggest in my $\mathrm{PhD}$ dissertation that festivals were becoming a new valuable resource in local development (Fournier 2005). Even if they had long been considered by 
social scientists as a time for excess, for waste or for social chaos, such festivals - especially in the most touristic areas - were now being valorised as cultural resources. In such a context, the people organizing them tried to transform them into new commodities. But in most of the cases, the traditional rituals were changed into playful moments as well. The people's idea was not only to transform the festivals into valuable economic features, but also to change the image of the places through the festivals. Entertainment was then replacing tradition. Like in many other sectors, local traditions were revived, rebuilt, reinvented, which led to question the very ways the reconstruction processes worked. Using constructivist history (Hobsbawm and Ranger 1983) as well as semiotics (Davallon 2002) I tried to understand how a larger audience was getting interested in these new festivals.

With the "Processional Giants and Dragons" example, however, there was something more to investigate, as the heritageization of the festivals did not come only from the locals but was also encapsulated in a much more global frame. Of course, the locals had to ask for the "Masterpiece of the Oral and Intangible Heritage of Humanity" label, but in practice they did very little for it. As an expert for the initial candidature in 2005, I knew that the different towns involved only gave a very short letter to certify that they accepted the candidature. In most of the cases the candidature file was supported by a little number of activists, while the town councils only accepted the idea afterwards. This meant that fieldwork ethnographical investigations in the festivals had to be completed by some sociological enquiries among the associations and the administrations involved in the nomination process. In other terms, it was not possible in this matter to take for granted the data which could be collected among the audience during the processions and the festivals. I had to seek for the voices of the actors, the administrators, the civil servants, etc., which supposed to enter another field of studies.

\section{SOME HYPOTHESES CONCERNING THE IMPACTS OF THE UNESCO POLICIES}

In this context, I felt I had to adapt my methods and to move slightly from the field of ethnography to the field of administrative sociology. This is why I decided to be less inductive than I usually was in my works on local festivals. In the 2009 report, therefore, I found useful to rely on five strong hypotheses concerning the impacts of the UNESCO policies on the field (Fournier 2009: 10-12).

My first hypothesis, which seems quite obvious, was that the impacts of the UNESCO policies could vary from one place to another. Some of the valorised elements, in connection with the local social or economic context, could be more impacted than others, which meant that we could use a simple hierarchic scale classifying the more or less impacted elements. The variations themselves could be connected with different indicators, such as the acceptance of the label by the locals, the reactions of the local politicians and the 
administrators, the visibility of the valorised element at a regional scale, or its success in the eyes of different sort of audiences.

My second hypothesis was that the impacts depended on the local radiation of the element. The impacts could vary according to the place the valorised elements hold among other cultural elements in the same geographical zone. In this case the variations depend on the place the valorised elements have in a specific cultural landscape. The UNESCO policies never occur in a neutral context: the history of an element and the history of the other comparable elements in the same area deeply influence the possible impacts of the UNESCO policies and have to be taken in account. In this context, the presence in the area of some elements already nominated on the 1972 list can be considered as especially significant.

My third hypothesis concerned the authenticity and the dynamics of the element. The impacts would vary according to the relations the different elements have with the notions of "identity", "tradition", "authenticity", etc. In this case, the impacts would be more (or less) important when the elements are more (or less) connected with authenticity. Indicators such as the age of the element and its ability to invest in the future would help to work out this hypothesis.

My fourth hypothesis stated that the impacts of a UNESCO policy were depending on the ability of the valorised elements to get connected with the issues of economic development and tourism. Here, the idea would be that the greater impacts occur when the cultural elements fit with the local economic and cultural policies, i.e. when there is a strong correspondence between the global and the local cultural policies.

My fifth and last hypothesis concerned the tradition-bearers. It supposed that the impacts of the UNESCO policies depended on the level of consciousness of the actors involved in the heritageization process. The more the people feel concerned and the more they feel they have become experts of their own culture, the greater the impacts will be.

All these different hypotheses were important because they could orientate further investigations on the field, either inside or outside the festivals. Moreover, they drew a frame through which the different cultural elements could be grasped. Accordingly, emphasis had to be put on the different actors at a local level, on the regional context, on authenticity, on tourism and on the economy. Fieldwork was thus launched on these bases.

\section{INTANGIBLE CULTURAL HERITAGE IN PRACTICE}

In 2009 a series of ethnographical investigations enabled to look at the different towns featuring "Processional Giants and Dragons" in France. All of the four towns concerned were investigated, although the case of Tarascon was considered with more intensity. In Tarascon, different local festivals have been observed during the year 2009, including of course the Tarasque festival in June where the dragon is traditionally shown. Comparative studies were conducted in Cassel, Douai and Pézenas, where the investigations tried to find 
out what the people knew about the other festivals included in the "Processional Giants and Dragons" group. Observing the differences between the different ways of valorising heritage in the different towns involved in the heritageization process enabled to know more about the homogeneity of this group of festivals.

Fieldwork, in many cases, also led to identify a gap between the official discourse of the UNESCO and what was really happening in the field. In the Tarasque festival in Tarascon, for instance, there is a lot of freedom in the performances and in the elaboration of the programme. The 2009 edition was clearly inspired by living history, featuring the reconstitution of the 1944 liberation struggle against the Germans, with the American GIs on display. The Tarasque legendary monster was accompanied by Tartarin, a hero of $19^{\text {th }}$ century novel writer Alphonse Daudet, on a military marine boat (Fig. 1). Coming from the river Rhone, another boat carries the musicians. The monster is disembarked and pulled up to the town where a procession is performed. The Medieval Tarasque, the $19^{\text {th }}$ century novel character and the American GIs all go together to the town hall in military trucks and in vintage cars. The festival's major elements during the week-end are the balls, the lunches in the streets of the old medieval town, the bull fights, the bowling competitions and the bonfires. Since 2005, the monster has been put all year long in a shop window in the old town and a stone sculpture has been carved and exhibited in front of the castle. By-products are sold out in shops and a new medieval Tarasque has appeared in August for the new medieval festival.

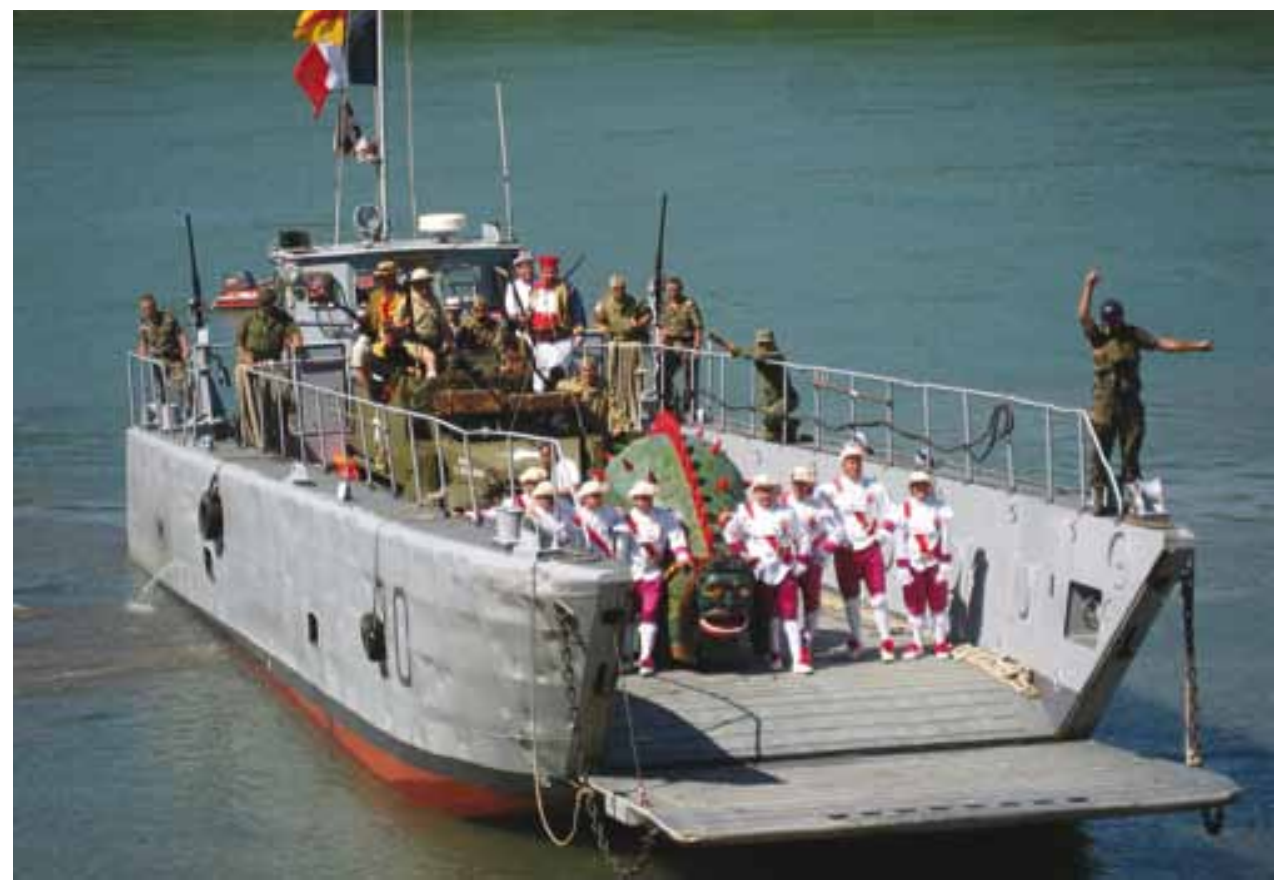

Figure 1 . The arrival of the Tarasque legendary monster on a military marine boat in Tarascon, France (photo: L. S. Fournier, 2009). 
In Pezenas, the ritual effigy is a pony. In 2009 during our fieldwork it was connected with the local rugby league and with the people trying to revive the regional "Occitan" dialect and culture. On the morning, the ritual pony is carried around the town by the local rugby men and the Occitan folk musicians. When passing by the fountains the people pretend they give the pony a drink. In the narrow streets of the old town the people give the pony a penny from their balconies. They revive the old practice of money-collecting. Other ritual animals from neighbouring villages join the procession. The goat from Montagnac or the donkey from Bessan, for instance, have not been recognized by the UNESCO but they feel they are similar to the pony and join the traditional gathering. After a stop at the local hospital, the procession heads to the stadium where a lunch is served at the club house. The pony has become an emblem for the rugby team, which is a very lively reinterpretation of the local tradition.

In Douai, in the North, there are five persons in the giant's family. The father and the mother are the bigger, more than six meters high and using nine persons to carry them around the streets. The three children, Jacquot, Bimbin and Fillon are smaller. Bimbin is famous for his squinting and for protecting little children from squinting. Around the giants are the money-collectors, the drums, and all the people carrying the giants. During the five days long festival which ends with the Bastille Day (July $14^{\text {th }}$ ), money-collections take place in all the different suburbs of the town, with the brass-band and with the town's mayor. On Sunday, there is also a great carnivalesque parade in a contemporary art style, featuring extraordinary machines, people on stilts or on rollers, confetti and a big fun-fair. Moreover, the Bastille Day celebrations bring their own programme, mainly balls and public concerts or sport events. After the five days, the giants go home in a shed where they will remain hidden until the next year's edition of the festival. In all the different "Processional Giants and Dragons" festivals, therefore, there is some evidence that a lot of things are going on besides the UNESCO emblems themselves.

Fieldwork during the festivals has been completed by interviews among the audience and the local organizers of the festivals. More than 30 people have been interviewed among the civil servants locally in charge of cultural heritage and tourism. The interviews showed that there was no real opposition between the local and the global scale: indeed, the locals have often met the people in charge of the nomination process at a global level. For instance, the people from Tarascon remember when the Tarasque dragon had been invited to India at the end of the 80 's. The show was organized by Charif Khaznadar, who then became an important UNESCO representative and helped a lot in the acknowledgment of the "Processional Giants and Dragons" as intangible cultural heritage. In the same way, the people in Douai and Cassel have been connected very early with Jean-Pierre Ducastelle, the director of the "House of the Giants" in Ath, Belgium, who was one of the main experts in the UNESCO nomination process prior to 2005.

In such a context, the researcher occupies an "in between" position. On the field, he is identified as an expert, but at the same time he can sometimes look a bit too nosy. For the actors of the festivals he appears as a representative of the Ministry of Culture and he is 
considered as potentially helpful, but most of the civil servants feel that he shouldn't learn them their job regarding the implementation of cultural heritage. In such a tricky position, the researcher is a mediator more than he provides an objective or external analysis. The topic of intangible cultural heritage therefore encourages reflexivity and the implication of the researchers on the field, side by side with the performers.

One of the most important local issues I went through during my investigations concerned the growth of tourism industry. In Tarascon the people in charge of this sector are especially willing to know if the UNESCO policies can bring more tourists. This is understandable because Tarascon suffers from the excellent cultural reputation of several neighbouring towns. Avignon, Arles, Nîmes and Aix-en-Provence attract most of the tourists in the famous area of Provence and they are all located at less than $50 \mathrm{~km}$ from Tarascon, and a lot of visitors just head for the Mediterranean Sea and miss Tarascon as well. In this context, the town of Tarascon dreams that her dragon could attract more people. When doing fieldwork, I was asked by the staff of the local tourist office to hand out a questionnaire to the tourists. About 350 questionnaires were filled in with the tourists during the summer of 2009. They were used as a supplementary tool in the analysis of the UNESCO policies' impacts and provided some more information in connection with the ethnographic studies and with the interviews.

\section{SOME RESULTS OF THE FIELDWORK}

The combination of ethnographic fieldwork, interviews among the administrators and questionnaires to the tourists enabled to reach some significant results concerning the impacts of the nomination of the "Processional Giants and Dragons" as intangible cultural heritage in France. Apart from discussing the hypotheses already mentioned above, these results help to compare the views of the different actors, the impacts in the different towns concerned by the label, and the differences between the initial project and its transformations five years after the nomination.

The first result is to bring together the views of the different actors involved in the field. It is then especially relevant to compare the positions of the experts at different scales. In the different places concerned by the nominations, activists willingly take part in the process, mainly through associations and other local networks. They use the new label to experiment strategies regarding the local implementation of cultural policies in general. In this respect, the UNESCO policies are only a pretext to discuss other local issues. As in each innovative process, there is a local polarisation between the ones who strongly believe in the benefits the label will bring in and the ones who criticize it and think of the new policies as a new means of domination used by the local elites against the people. When asking the people in charge of the implementation of the UNESCO policies at a higher level, however, the positions are different. According to a museum curator, for instance, the main 
issue would be the one of managing the new label without any special financial counterpart from the UNESCO. The regional administrations would like to use the new UNESCO policies but they find that they are disconnected from the French national cultural policies. But these problems are far beyond the concerns of the UNESCO representatives, who consider France as a wealthy country which should manage alone the implementation of the Convention. According to the UNESCO, there would therefore be a mismatching in the fact that the Convention is dedicated to poor countries whereas the rich countries are the more competitive in proposing cultural elements for the nomination process.

Another result consists in comparing the impacts of the UNESCO policies in the different towns where the "Processional Giants and Dragons" appear. Some differences between the four towns of Cassel, Douai, Pézenas and Tarascon can be emphasized. In Tarascon, the general impact regards the visibility of the processional dragon. The Tarasque dragon was traditionally hidden out of the time of the procession; it is now exhibited in a special show-case in the centre of the medieval town, as we have already mentioned. Moreover, a monumental stone sculpture is now on display in front of the local castle (Fig. 2). The "Tarascaïres", the Tarasque-pushers, are more and more invited in other festivals around the year, both in France and abroad. Accordingly, they feel they have to become more professional in performing their traditions. From the point of view of the people from the tourist office and of the people locally in charge of the festivals, nothing has been done yet but they ask for some help to valorise the new label. The people in charge of the cultural heritage have launched several exhibitions on the topics of dragons, the medieval times and the imaginary. For their part, shopkeepers began selling books, mugs or key-rings featuring the Tarasque dragon just after the label was granted by the UNESCO. In the other towns, like in Pézenas or Douai, the impact seems less visible as the regions are less attractive than Provence. In these cases, the traditions rely on partnerships with local cultural associations. Sometimes, the local sportsmen also help as they are fit enough to carry the heavy effigies, like the rugby men in Pézenas (Fig 3). In Cassel, a museum has opened in 2010 to present some of the local traditions, including the UNESCO ones.

A last result comes from comparing the initial project and its transformations. Before the nomination all candidates are asked to make some previsions at a five years term. In the case of the "Processional Giants and Dragons", different points were mentioned in the 2005 candidature file. Several meetings were to be held between 2006 and 2010 among the people in charge of the processions and an itinerant exhibition was supposed to move from one town to another every two months to reinforce the connections between the different cities involved in the nomination. A catalogue of this exhibition was to be published and emphasis was to be put on the giants and dragons makers as well. In 2009, a meeting of all the giants and dragons was supposed to prepare the five years term evaluation by the UNESCO. Five years later the report shows that only the first point - the 2006 meeting - had been realised. All the other events didn't happen. Sometimes this was due to the lack of financial resources. Sometimes, the people in charge of the implementation of the 

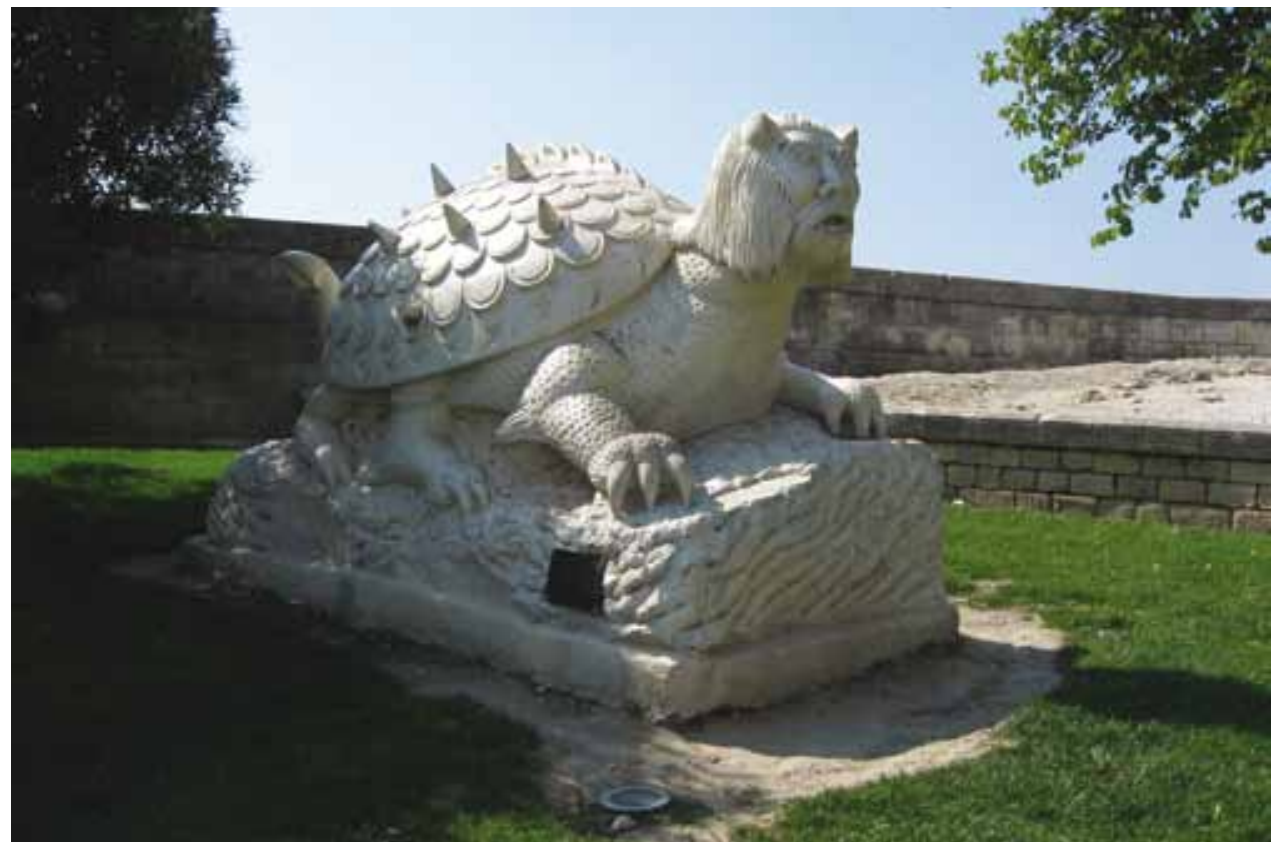

Figure 2. The new visibility of the monster: A monumental stone sculpture of the Tarasque, now on display in front of the local castle in Tarascon, France (photo: L. S. Fournier 2009).

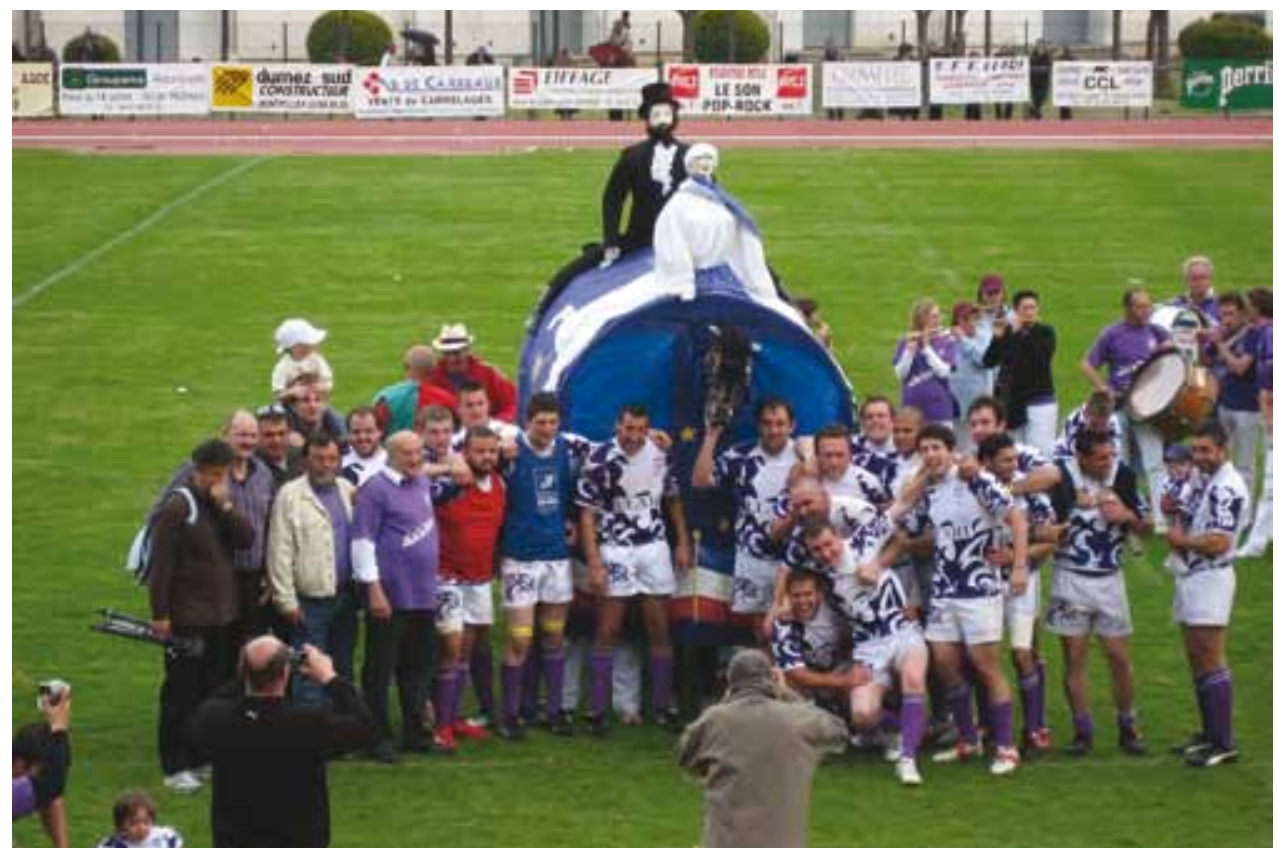

Figure 3. Joining the rugby team. The traditional pony, a new emblem for sports in Pezenas, France (photo: L. S. Fournier 2009). 
Convention were transferred in other places; some of them died; new people were elected, etc. Such a comparison shows that the UNESCO policies are more indicative than prescriptive. They strongly depend on the context, which legitimates a study of the different ways they are implemented in the different states concerned by the Convention.

\section{INTANGIBLE CULTURAL HERITAGE IN FRANCE}

Concerning the French case, understanding the intangible cultural heritage needs to pay attention both to the history of cultural heritage in general and to the administrations in charge of the UNESCO policies in particular.

Broadly speaking, the notion of cultural heritage is deeply anchored in the French universalistic doctrine since the 1789 Revolution (Chastel 1986). When the castles and the cathedrals were abandoned and destroyed by the revolutionary, the left-wing constitutionalist priest Abbé Grégoire pleaded that they should be preserved and protected for the nation's sake. Such valuable goods had to be considered as common goods, "res publica" in Latin, which brings together the ideas of cultural heritage and the Republic itself. From then, the idea of preserving a cultural heritage was deeply connected with the building of a modern nation-state in France. During the $19^{\text {th }}$ century a list of remarkable goods was established and inspectors were appointed by the state to inventory the cultural heritage in the different regions and to reinforce the new central nation-state's radiation, insisting on the monuments and the fine arts.

At the end of the $19^{\text {th }}$ century, however, the leftists complained about the criteria according to which the cultural heritage was inventoried. The avant-garde painters thought that modern paintings were as much important as the Renaissance ones; the factory workers said that the industrial buildings were sometimes more valuable than the old romantic ruins or chapels; the regionalists asked for regional folklore artefacts to be put into the museums. In this context, the aesthetical views commanding cultural heritage were dramatically changed. Heritage was becoming a matter of taste. In the 1930s' the anthropologist Marcel Mauss said that "a tin-box tells us more about our society than the most precious jewel" (Jamin 1989). Connections between anthropologists and surrealist poets led to define the new field of "popular arts and traditions" and to a renewal in the accepted definitions of cultural heritage.

From then, cultural heritage was slightly split apart. The historians, the art historians and the architects kept insisting on the accepted definition, encompassing the monuments and the fine arts and valorising the museums, whereas the anthropologists and the folklorists developed the notion of "ethnological heritage", including industries, crafts, popular culture, etc., which had to be preserved "in situ". As a head of the ICOMOS, Georges-Henri Rivière, the founding curator of the "Musée national des arts et traditions populaires" in Paris had a leading role in this reflection after World War II. However, this new trend was a schism regarding the universalistic doctrine of the French nation-state. Emphasizing cultural diversity instead 
of national unity is often considered as a threat by the national French elites, which means that the French doctrine of cultural heritage is still a significant place for political struggles.

Today, the implementation of intangible cultural heritage reflects some of these historical features. There is an ambiguity connected with the fact that it is the civil servants from the central nation-state who should sort out and accept the proposals coming from the different French regions. In a country where all the different political and administrative elites need to train in the most prestigious Parisian schools, the provinces are still very much seen as peripheries. Nobody could seriously think that the national genius would burst in some remote countryside resort, when the eyes of the international art critique are systematically turned towards the Louvre and the Parisian milieu. This is also a reason why the word "folklore" in French is rather despised and laughed at.

Concerning the very case of intangible cultural heritage, the administrative situation in France is as following. The French Commission for the UNESCO is a branch from the Ministry for Foreign Affairs and as such it doesn't really bother with the French internal affairs. According to its representatives, there is no need to worry with the French intangible cultural heritage as there are no diplomatic conflicts concerning heritage in France. As soon as there are no such conflicts, there is no need to help the different communities involved in the UNESCO policies in France. This is as much understandable as the term "community" has no legal existence in the frame of the universalistic doctrine of the French nation-state. It is then a special branch of the Ministry of Culture, the "Mission à l'ethnologie" who deals with the UNESCO policies and with the intangible cultural heritage in France. After 30 years of research on "ethnological heritage", this "Mission à l'ethnologie" has begun since 2006 to inventory possible candidates and to propose special files to the actors interested in the nomination process (Hottin 2011). Furthermore, several researchers have been asked to imagine common methods concerning the implementation of the elements already nominated as well as the future nominations. But the action of the "Mission à l'ethnologie" is limited to the field of culture, which means that no real connections with the fields of local development or tourism which deeply concern the local actors have been built up yet.

However, eight new cultural elements have been granted the intangible cultural heritage label by the UNESCO after the "Processional Giants and Dragons". In 2009 there were four: the "Cantu a paghjella", a secular and liturgical oral tradition of Corsica, the Aubusson tapestry, the Maloya dance from La Réunion French island in the Indian Ocean, and the scribing tradition in French timber framing. In 2010 there were four more: the "Compagnonnage", a network for on-the-job transmission of knowledge and identities, the art of falconry, the gastronomic meal of the French, and the craftsmanship of Alencon needle lace-making. A quick survey of these eight different examples shows first that there is an interesting balance between the "rituals and festivals" group and the "arts and crafts" group within the Convention. Second, comparing the different elements shows that the communities can be candidates for different reasons. Some of the files were really boosted by the locals, like the "Cantu a paghjella" which is significant for the Corsican nationalists 
struggling for independence or the Maloya dance which is seen as a means to legitimize the culture of a French island overseas and therefore has a lot to do with the discussion over the French colonial past. In other cases, however, the local actors had to be asked for some cooperation. Concerning the "Compagnonnage" the candidature file had to be completed with the help of a young anthropologist whose work was precisely devoted to this community (Adell-Gombert 2008). Concerning the art of falconry the candidature was an international one and the local performers in France were invited by the Ministry of Culture to participate with a French contribution. Concerning the Alencon needle lace-makers they were only less than a dozen practitioners left so it was really a matter of safeguard. Concerning the gastronomic meal of the French, lastly, the candidature was directly proposed by the French president Nicolas Sarkozy against the will of many civil servants in charge of the UNESCO affairs in France.

\section{CONCLUSION}

On the whole, all these examples clearly show that each different cultural form can meet different reactions in the public sphere as soon as they try to be acknowledged as intangible cultural heritage. In order to understand better these reactions, the French Ministry of Culture has been very active since 2008. First, as France's self-representation is deeply connected with philosophy, an academic seminar on intangible cultural heritage has been launched at the École des Hautes Études en Sciences Sociales in Paris (Bortolotto 2011). Second, different meetings have been organized with the help of the professional networks of museum workers and curators to identify new potential candidates. Third, a special effort concerns the inventory of intangible cultural heritage. I have myself begun to collect files concerning traditional games in France under a special format, and the Ministry of Culture has published a handbook together with the "French Center for Intangible Cultural Heritage" (Hottin 2011).

However, despite such efforts, the popular reactions towards the implementation of intangible cultural heritage can sometimes be very difficult to understand. For instance in 2009 a community in the Bretagne area refused to have their local procession protected under the UNESCO label because they felt the label would give too much power to the organizers of the procession, which were belonging to the church. The heritage building process had to stop after a massive protest from the local landowners. This last example clearly shows that the implementation of intangible cultural heritage policies always strongly depends on the context. This context is at once a national one, but it is also an economic one, as have shown my fieldwork in France, where intangible cultural heritage is strongly connected with the issues of local development and tourism.

On these bases, anthropologists have a lot of work to do. The field is rich as it is connected with the interests of neighbouring social sciences. To finish, I will then suggest that 
the impacts of the intangible cultural heritage UNESCO policies are not only visible on the field, but also in the academia where the study of the intangible cultural heritage related processes appears as a good opportunity to develop "heritage studies" and to improve the cooperation between the researchers and the performers.

\section{REFERENCES}

Adell-Gombert, Nicolas

2008 Des hommes de devoir. Les compagnons du Tour de France (XVIIIe-XXe siècles). Paris: Maison des Sciences de l'Homme.

Bortolotto, Chiara (ed.)

2011 Le patrimoine culturel immatériel. Enjeux d'une nouvelle catégorie. Paris: Maison des Sciences de l'Homme.

Chastel, André

1986 La notion de patrimoine. In : Nora, Pierre (ed.), Les lieux de mémoire. Vol. II, 2. Paris: Gallimard, 405-450.

Davallon, Jean

2002 Comment se fabrique le patrimoine? Sciences Humaines 36: 74-77.

Fournier, Laurent Sébastien

2005 La fête en héritage. Enjeux patrimoniaux de la sociabilité provençale. Aix-en-Provence: Publications de l'Université de Provence.

2009 L'impact de l'appellation «Chefd'euvre dupatrimoine oral et immatériel del'humanité» en France. Le cas des géants et dragons processionnels. Paris: Mission à l'ethnologie, Ministère de la Culture et de la Communication.

Hobsbawm, Eric and Terence Ranger (eds.)

1983 The Invention of Tradition. Cambridge: Cambridge University Press.

Hottin, Christian

2011 Sept ans, l'âge de raison. Dynamique et enjeux du patrimoine culturel immatériel. In: Lepatrimoine culturel immatériel. Premières expériences en France. Paris: Babel-Maison des Cultures du Monde, $27-56$.

Jamin, Jean

1989 Le musée d'ethnographie en 1930. In:La muséologie selon Georges-Henri Rivière. Cours de muséologie, textes et témoignages. Paris: Dunod-Bordas, 110-121.

\section{VPLIVI UNESCOVE POLITIKE NESNOVNE KULTURNE DEDIŠČINE V FRANCIJI}

Članek temelji na poročilu iz leta 2009, pripravljenem za francosko ministrstvo za kulturo,o vplivu imenovanj nesnovne kulturne dediščine na turizem (Fournier 2009). Študija primera je posebej obravnavala "Procesije velikanov in zmajev v Belgiji in Franciji", ki so bili leta 2005 uvrščeni med "Mojstrovine ustne in nesnovne dediščine človeštva" in leta 2008 vključeni $v$ "Reprezentativni seznam nesnovne dediščine človeštva". 
Da bi bolje spoznali "Procesije velikanov in zmajev", je koristno najprej pregledati Unescovo spletno stran. Po Unescovi uradni predstavitvi pod oznako "Procesije velikanov in zmajev v Belgiji in Franciji "najdemo tradicionalne procesije ogromnih figur velikanov, živali in zmajev $v$ izvirni celoti popularnih prazničnih manifestacij in ritualnih predstavitev.

$V$ zvezi z učinki Unescove politike članek obravnava pet podmen. Prva je, da se v Franciji vplivi labko razlikujejo od kraja do kraja. Druga podmena je, da so učinki odvisni of lokalne razširjenosti elementa. Tretja se nanaša na avtentičnost in dinamiko elementov z Unescovo nalepko. Čtrta postavlja, da je učinek Unescove politike odvisen od zmožnosti, da se ovrednotene elemente poveže z vidiki gospodarskega razvoja in turizma. Peta in zadnja podmena zadeva nosilce tradicije: učinki Unescove politike so v tem pogledu odvisni od ravni zavesti akterjev, udeleženih $v$ procesu dedišcinjenja.

Leta 2009 speljanje etnografske raziskave so omogočile pogledati v različne kraje v Franciji, kjer prirejajo "Procesije velikanov in zmajev". Terensko delo je v več primerih pripeljalo $k$ ugotovitvi o razlikah med uradnim Unescovim diskurzom in tem, kar se je dejansko dogajalo na terenu. Terensko delo $v$ času festivalov je zajemalo pogovore med lokalnimi uslužbenci, odgovornimi za kulturno dedišcino in turizem. Pogovori so pokazali, da med lokalno in globalno ravnijo ni bilo pravih nasprotij: nasprotno, domačini so se pogosto srě́ali z ljudmi, odgovornimi v procesu imenovanja na globalni ravni.

Kombinacija etnografskega dela na terenu, pogovorov z uradniki in vprašalnikov za turiste omogoča pomenljiva spoznanja o vplivih imenovanja "Procesij velikanov in zmajev"kot nesnovne dedišcine $v$ Franciji. Razen razprave o omenjenih podmenah spoznanja pomagajo primerjati poglede različnih akterjev, vplive $v$ različnih krajih in razločke med začetnim projektom in njegovimi spremembami pet let po imenovanju.

Spoznanja prispevajo $k$ boljšemu razumevanju zgodovinskih značilnosti nesnovne kulturne dediščine v Franciji. Danes uveljavitev nesnovne kulturne dediščine odseva nekatere od njih, hkrati pa je nekaj novih kulturnih elementov pridobilo Unescovo nalepko nesnovne kulturne dediščine. V celoti različni primeri jasno kažejo, kako so različne kulturne oblike različno sprejete $v$ javnosti, ko so priznane za nesnovno kulturno dediščino.

Avtor v sklepu ugotavlja, da vpliv Unescovega koncepta nesnovne kulturne dediščine ni opazen le na terenu, temveč tudi v akademskih krogih, kjer so raziskave procesov, povezanih z nesnovno kulturno dediščino, dobra priložnost za razvoj "raziskav dediščine ter boljše sodelovanje med raziskovalci in poustvarjalci.

Laurent Sébastien Fournier, PhD, UFR STAPS et EA 3260 CENS, Université de Nantes 25 bis, Bd. Guy Mollet, BP 72206, 44322 Nantes cedex 3, France, laurent.fournier@univ-nantes.fr 